University for Business and Technology in Kosovo

UBT Knowledge Center

UBT International Conference

2014 UBT International Conference

Nov 8th, 2:30 PM - 2:45 PM

\title{
Land suitability location analysis for housing development using GIS
}

\author{
Rizah Murseli \\ University of Prishtina, rizah.murseli@gmail.com \\ Florim Isufi \\ University of Prishtina, florim_isufi@yahoo.com
}

Follow this and additional works at: https://knowledgecenter.ubt-uni.net/conference

Part of the Architecture Commons

\footnotetext{
Recommended Citation

Murseli, Rizah and Isufi, Florim, "Land suitability location analysis for housing development using GIS" (2014). UBT International Conference. 18.

https://knowledgecenter.ubt-uni.net/conference/2014/all-events/18

This Event is brought to you for free and open access by the Publication and Journals at UBT Knowledge Center. It has been accepted for inclusion in UBT International Conference by an authorized administrator of UBT Knowledge Center. For more information, please contact knowledge.center@ubt-uni.net.
} 


\title{
Land suitability location analysis for housing development using GIS
}

\author{
Rizah Murseli ${ }^{1}$, Florim Isufi ${ }^{2}$ \\ ${ }^{12}$ University of Prishtina, Mother Theresa street no number, 10000 Prishtina, Kosovo \\ rizah.murseli@gmail.com ${ }^{1}, \underline{\text { florim_isufi@yahoo.com }}{ }^{2}$
}

\begin{abstract}
Application and implementation of location suitability analyses are powered through the use of GIS along with spatial analysis component, which enables the creation of buffers, overlay, termination, proximity analysis, spatial unity, map algebra, reclassification of raster and other operations. In terms of land suitability, GIS helps the user to define which locations are most appropriate or inappropriate for certain developments. Consequently, GIS as a tool becomes more important to provide support for decision makers. This analysis takes into account environmental and socioeconomic factors as determinant of urban land development. This analysis requires first finding spatial, environmental and socio-economic constraints and then finding the land suitable for development of residential areas according to specified criteria's. Hence, two preliminary results derive mainly from this analysis, such as composite (raster) map of restrictions for housing developments, and composite (raster) map of suitability housing development. Once these two composite maps are completed using specified GIS operations and functions, it is created the final map of site suitability for housing development. In creating the final map several factors had been used in total to establish the restriction model and also many criteria's divided into five classes for establishing a map of land suitability for residential development in Prishtina city, namely in the study area.
\end{abstract}

Keywords: GIS, Modeling, Spatial Analysis, Location Suitability, Map Algebra.

\section{Introduction}

This analysis is very useful for decision makers, planners and developers who will planed and invest different projects in different locations. Location influence almost everything in human development needs. Some future development are specific to specific locations. The land suitability term has to do with its features required to support a proposed land use, taking into account social, physical, spatial, and economic factors. Land suitability analysis (LSA) is an analysis which is based on a combination of many GIS operations and functions for assessing the land suitability locations for certain developments, in this case for residential development. This spatial analysis uses algebraic language of map taking into account given factors as conditional to urban land development. Hence, Map Algebra is a simple and powerful algebra with which can be executed all operations and functions of Spatial Analysis tools for Geographical Analysis.

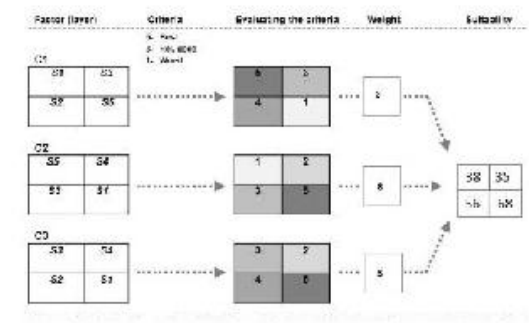

Fig. 1. The scheme how the calculations process operates in spatial analysis. Source: ESRI, ArcGIS Spatial Analysis (Adopted by R. Murseli \& F. Isufi). 
The aim of this research is to find out which are the most suitable locations for the allocation of land for future urban - residential developments based on given and required factors and criteria. Conducting this analysis initially requires finding spatial, environmental and socioeconomic constraints and then finding the land suitability for specific developments based on defined parameters. So, mainly two preliminary results come through this analysis, as follows:

1. A composite (raster) map of residential development restrictions, and

2. A composite (raster) map of the suitability of residential developments.

Once these two composite maps are completed using GIS certain operations and functions, the final map of land suitability for development is created.

Based on data provided and for the purposes of this research was developed the Final Model of Land suitability for Residential Development, with two main supporting models of restrictions and suitability as follows:

1. The final suitability model for residential development (FSMRD),

a. Restriction model for residential development (RMRD);

b. Suitability model for residential development (SMRD);

Application and conducting of these analyzes is enabled through the use of GIS together with spatial analysis tools, which allows the creation of buffers, overlay, termination, proximity analysis, spatial unifications, map algebra, raster reclassification and other operations . In terms of land suitability, GIS helps the user to define which sites are suitable or unsuitable for development. In this way, GIS as a tool becomes very important, providing support for decision makers.

In building a model are required eight steps, which are achieved through spatial analysis, which include: defining the criteria for analysis, defining the necessary data, defining what GIS analysis operations should be performed, preparation of data, design a model, activation of the model, analysis of model results, and Refining the model as it needed.

\section{Defining the criteria for analysis}

During the planning process two steps are very important, the first step is to know and locate which area important resources to preserve or restrict for future development in an area and second step is what is left from preserve or restrict resources to plane then to develop for future development. Defining the criteria is made based on the restrictions of spatial developments arising as part of the national legislation, planning documents (Estimated investment in infrastructure), analyzing the most appropriate distance for land functions dedicated for housing, as well as documents and different practices. Here is very important to know the methodology and the benefits of this analysis than the results itself. Criteria's have been taken from various local urban plans and some set up criteria's which exercise here are in this paper.

The formula for calculating the land suitability is:

$$
S=\sum_{i=1}^{n} w_{i} C_{i} \prod_{j=1}^{m} r_{j}
$$

Where:

$\mathrm{S}=$ Suitability model for residential development;

$w_{i}=$ Weight for criteria $i\left(C_{i}\right)$;

$C_{i}=$ Criterion for suitability;

$r_{j}=$ Restrictions (stops).

Weight and criteria for suitability model:

- $w_{1} \& C_{1}=$

- $w_{2} \& C_{2}=$

- $w_{3} \& C_{3}=$

- $w_{4} \& C_{4}=$
Weight and criteria for economic zones;

Weight and criteria for healthcare services;

Weight and criteria for recreation (parks, sport) areas;

Weight and criteria for education (schools and preschools) services; 
- $w_{5} \& C_{5}=$

Weight and criteria for existing residential areas;

- $w_{6} \& C_{6}=$ Weight and criteria for water supply accessibility;

- $\quad w_{7} \& C_{7}=$

- $w_{8} \& C_{8}=$

Weight and criteria for canalization network accessibility;

- $w_{9} \& C_{9}=$

Weight and criteria electric network accessibility;

- $w_{10} \& C_{10}=$

Weight and criteria for roads accessibility;

- $w_{11} \& C_{11}=$

Weight and criteria for slope conditions;

Weight and criteria for aspect conditions;

Tab. 1. Factors and criteria's for suitability model for residential development

\begin{tabular}{|c|c|c|c|c|c|c|c|}
\hline $\begin{array}{l}\text { Fact } \\
\text { or/ } \\
\text { Crit } \\
\text { eria }\end{array}$ & $\begin{array}{l}\text { S1 } \\
(5)\end{array}$ & $\begin{array}{l}\text { S2 } \\
(4)\end{array}$ & $\begin{array}{l}\text { S3 } \\
\text { (3) }\end{array}$ & $\begin{array}{l}\text { S4 } \\
(2)\end{array}$ & $\begin{array}{l}\text { S5 } \\
(1)\end{array}$ & W & 0 \\
\hline $\mathrm{C}_{1}$ & $<1.5 \mathrm{~km}$ & $\begin{array}{c}1.5- \\
3.0 \mathrm{~km}\end{array}$ & $\begin{array}{c}3.0- \\
5.0 \mathrm{~km}\end{array}$ & $5.0-10 \mathrm{~km}$ & $\mathrm{~m}^{>10.0 \mathrm{k}}$ & 0.04 & \multirow[t]{5}{*}{$.00^{20}$} \\
\hline $\mathrm{C}_{2}$ & $0.5 \mathrm{~km}$ & $\begin{array}{c}0.5- \\
1.5 \mathrm{~km}\end{array}$ & $\begin{array}{l}1.5- \\
3.0 \mathrm{~km}\end{array}$ & $3.0-5.0 \mathrm{~km}$ & $>5.0 \mathrm{~km}$ & 0.04 & \\
\hline $\mathrm{C}_{3}$ & $<0.5 \mathrm{~km}$ & $\begin{array}{c}0.5- \\
1.5 \mathrm{~km}\end{array}$ & $\begin{array}{l}1.5- \\
3.0 \mathrm{~km}\end{array}$ & $3.0-5.0 \mathrm{~km}$ & $>5.0 \mathrm{~km}$ & 0.04 & \\
\hline $\mathrm{C}_{4}$ & $0.5 \mathrm{~km}$ & $\begin{array}{c}0.5- \\
1.5 \mathrm{~km}\end{array}$ & $\begin{array}{c}1.5- \\
3.0 \mathrm{~km}\end{array}$ & $3.0-5.0 \mathrm{~km}$ & $>5.0 \mathrm{~km}$ & 0.04 & \\
\hline $\mathrm{C}_{5}$ & $0.2 \mathrm{~km}$ & $\begin{array}{c}0.2- \\
0.5 \mathrm{~km}\end{array}$ & $\begin{array}{c}0.5- \\
1.0 \mathrm{~km}\end{array}$ & $1.0-2.0 \mathrm{~km}$ & $>2.0 \mathrm{~km}$ & 0.04 & \\
\hline $\mathrm{C}_{6}$ & $<0.1 \mathrm{~km}$ & $\begin{array}{r}0.1- \\
0.25 \mathrm{~km}\end{array}$ & $\begin{array}{l}0.25- \\
0.5 \mathrm{~km}\end{array}$ & $0.5-2.0 \mathrm{~km}$ & $>2.0 \mathrm{~km}$ & 0.10 & \multirow[t]{4}{*}{$.00^{40}$} \\
\hline $\mathrm{C}_{7}$ & $<0.2 \mathrm{~km}$ & $\begin{array}{c}0.2- \\
0.5 \mathrm{~km}\end{array}$ & $\begin{array}{c}0.5- \\
1.0 \mathrm{~km}\end{array}$ & $1.0-2.5 \mathrm{~km}$ & $>2.5 \mathrm{~km}$ & 0.10 & \\
\hline $\mathrm{C}_{8}$ & $<0.2 \mathrm{~km}$ & $\begin{array}{c}0.2- \\
0.5 \mathrm{~km}\end{array}$ & $\begin{array}{c}0.5- \\
1.0 \mathrm{~km}\end{array}$ & $1.0-2.5 \mathrm{~km}$ & $>2.5 \mathrm{~km}$ & 0.10 & \\
\hline $\mathrm{C}_{9}$ & $0.25 \mathrm{~km}$ & $\begin{array}{l}0.25- \\
0.5 \mathrm{~km}\end{array}$ & $\begin{array}{l}0.5- \\
1.0 \mathrm{~km}\end{array}$ & $1.0-2.5 \mathrm{~km}$ & $>2.5 \mathrm{~km}$ & 0.10 & \\
\hline $\mathrm{C}_{10}$ & $0-2^{0}$ & $2-5^{0}$ & $5-8^{0}$ & $8-15^{0}$ & $>15^{0}$ & 0.25 & \multirow[t]{2}{*}{$.00^{40}$} \\
\hline $\mathrm{C}_{11}$ & South & $\begin{array}{l}\text { Sout } \\
\text { h-East }\end{array}$ & $\begin{array}{l}\text { South- } \\
\text { West }\end{array}$ & $\begin{array}{l}\text { North- } \\
\text { West \& North- } \\
\text { Est }\end{array}$ & Null & 0.15 & \\
\hline 11 & \multicolumn{5}{|c|}{ Sum } & 1.00 & $0^{10.00}$ \\
\hline
\end{tabular}

Restriction factors and criteria:

- $r_{l}=\quad$ Restriction related to road (street);

- $r_{2}=$ Restriction related to railway;

- $r_{3}=$ Restriction related to water deposits;

- $r_{4}=\quad$ Restriction related to high electric power line;

- $r_{5}=\quad$ Restriction related to high voltage electric stations (TS);

- $r_{6}=$ Restriction related to public institutions;

- $r_{7}=\quad$ Restriction related to cemetery;

- $r_{8}=\quad$ Restriction related to river bad;

- $r_{9}=$ Restriction related to existing forest areas;

- $r_{I 0}=$ Restriction related to riparian woods;

- $r_{l l}=$ Restriction related to parks;

Tab. 2. Factors and criteria's for restriction model for residential development.

\begin{tabular}{lll}
\hline Factor & Described factor & Criteria \\
\hline
\end{tabular}




\begin{tabular}{lll}
\hline $\boldsymbol{r}_{1}$ & National road (within urban areas) & $6 \mathrm{~m}$ \\
& Primary urban road & $6 \mathrm{~m}$ \\
& Collective urban road & $6 \mathrm{~m}$ \\
& Local urban road & $3 \mathrm{~m}$ \\
& Special urban road & $3 \mathrm{~m}$ \\
$\boldsymbol{r}_{\mathbf{2}}$ & Rural road & $3 \mathrm{~m}$ \\
$\boldsymbol{r}_{3}$ & Railway & $3 \mathrm{~m}$ \\
$\boldsymbol{r}_{\mathbf{4}}$ & Water deposit & $10 \mathrm{~m}$ \\
$\boldsymbol{r}_{\mathbf{5}}$ & High voltage electric power line & $100 \mathrm{~m}$ \\
$\boldsymbol{r}_{\mathbf{6}}$ & Pigh voltage electric stations (TS) & $100 \mathrm{~m}$ \\
$\boldsymbol{r}_{7}$ & Cemetery & $10 \mathrm{~m}$ \\
$\boldsymbol{r}_{\boldsymbol{8}}$ & River & $10 \mathrm{~m}$ \\
& Stream & $30 \mathrm{~m}$ \\
$\boldsymbol{r}_{9}$ & Forest area & $10 \mathrm{~m}$ \\
$\boldsymbol{r}_{10}$ & Riparian wood & $5 \mathrm{~m}$ \\
$\boldsymbol{r}_{11}$ & Parks & $5 \mathrm{~m}$ \\
\hline & & $10 \mathrm{~m}$ \\
\hline
\end{tabular}

\subsection{Specification of the Necessary Data}

The model operates through geographic data, and as much precise the geographic data are and as better the weight and scale of these data defined, so the most acceptable are the model results. In the analysis of land suitability model for residential developments, as well as models of development constraints have been used the following data:

1. Land Use - Geo-database of land use for Prishtina city in 2013, developed by R. Murseli Master thesis;

2. Water supply network- the data is provided by RWC Prishtina and has accuracy equivalent to land use map;

3. Sewerage network - the data is provided by RWC Prishtina and has accuracy equivalent to land use map;

4. Local electricity network - the data source is KEDS and has accuracy equivalent to land use map;

5. Road network - the data is developed by R. Murseli Master thesis;

6. Digital relief model (10x10m pix.) - The data is developed from topographic maps 1:25000 as isolines;

7. The slope of the terrain and aspects (10x10m pix.).

\subsection{Setting Operations - Function in GIS}

Based on the criteria and data set for the establishment of relevant models, the next necessary step is to set operations-functions in GIS, which are necessary for specifying the land suitability. Almost all files must be converted from vector to raster. Then, the raster should be reclassified in the classification system from 0 and 1 for restrictions model and from 1 to 5 classes for the land suitability model, where the value 0 indicates preservations or restrictions, and value 1 (S5) shows the worst suitability and value 5 (S1) shows the best suitability. Then, it becomes the integration of the model of restrictions and suitability to produce the final model of suitability.

All values of the model of suitability should be extended within cells of value 1 of the restrictions model. The buffer operation should be applied to all files in the model of restrictions, with the aim of including restrictions distance for certain developments. For example, the protective area of river has $30 \mathrm{~m}$ buffer, while the urban local roads $3 \mathrm{~m}$ buffer from the edge of the road or sidewalk (regulative 
line). In the model of limitations each pixels that falls in the value of 0 indicates restrictions of that space, and the value 1 indicates that there are no restrictions. But at the model of suitability, each cell with value 1 indicates the lowest or poor suitability, while the cell with the value 5 indicates the highest suitability. Because the study area is small and S5 and S4 sometimes extend it, the classes might not be shown in the suitability maps.

\subsection{Data preparation}

After setting GIS operations, data should be prepared for the model. This includes cut-off data within the study area; classification of data and some conversions of vectors into raster.

\subsection{Setting the Model}

Setting the model is done in Model Builder application in ArcView program. In this application we can activate the above GIS operations and execute at the defined data using classification by weight and scale. So, the model builder is an application for building, editing and management of the model or models.

\subsection{Model Activation}

Model activation is made in the application where the model is built through the command "Run Model". In this phase, which is followed by the building phase is designed the map for what the model is built, in this case becomes the mapping of land suitability for residential development.

\subsection{Analysis of Model Result}

At this stage the model results are analyzed, if they have given the desired result based on data of defined criteria and operations performed in GIS. If the model is acceptable, then the final map of land suitability is prepared, if not then we substitute the GIS operations or change the criteria or factors as it has been describe above as refining the model.

\section{Conclusion}

In many municipalities in Kosovo not to say It has become a habit, that during the planning process and especially when the need of the urban growth boundary and designation of areas for future development are made under the influence of subjective factors, and as a result the urban boundaries expanded in an inappropriate locations, also intended surface settlements in unsuitable locations and often with a high degree of risk or even in areas with restriction development. Also, natural resources and values are not observed due to the interference of political interests and other interest groups. Analysis of location suitability when It needed enables the urban growth boundary or the development of new residential areas or other, to becomes so scientific, fair, transparent and practical, eliminating largely subjective factors that often influence the inadequate plans and therefore not sustainable investments, which do not serve well to community and neither local government nor the investors. This analysis is not saying that will solve the problems of urban planning, but enable the development of new areas of development in order to become fairer and more appropriate in locations term. 


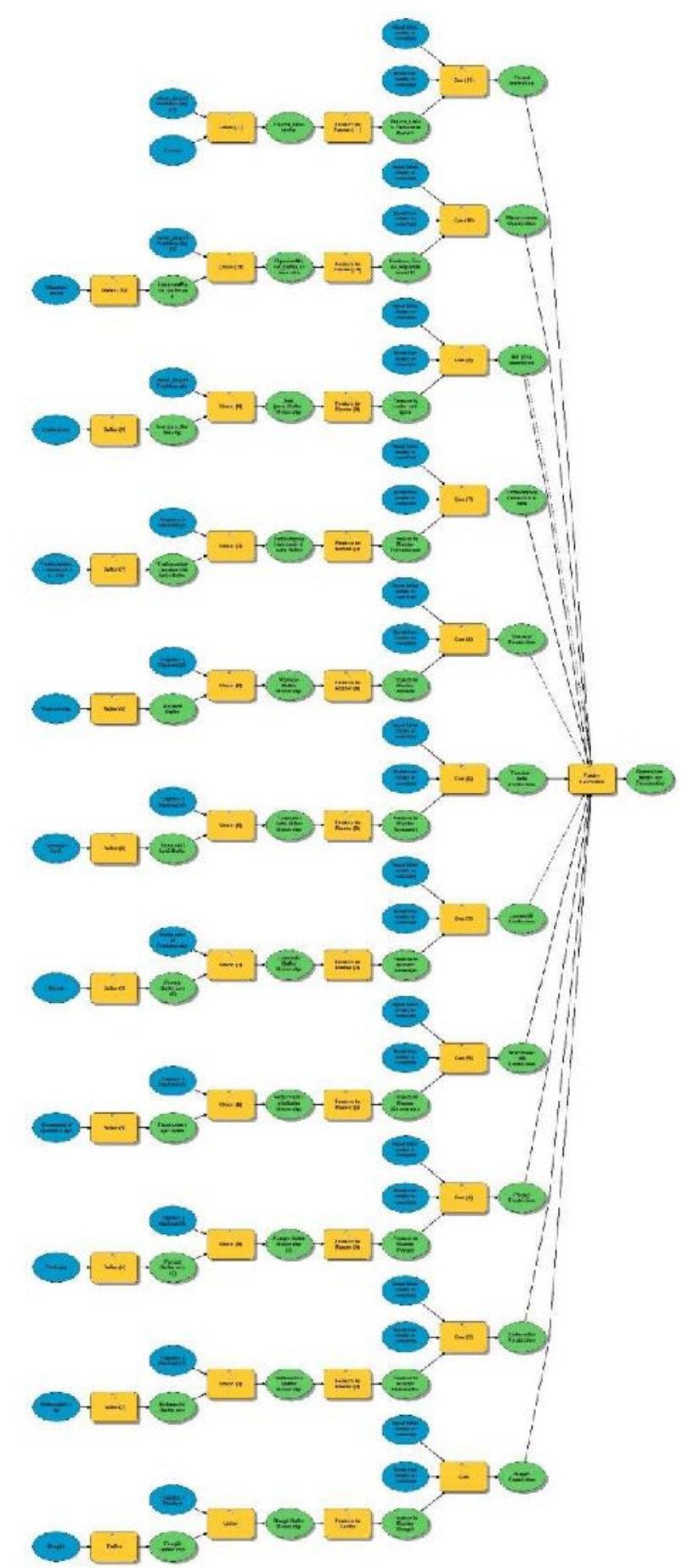

Fig. 2. Operational scheme of restriction model (By authors). 


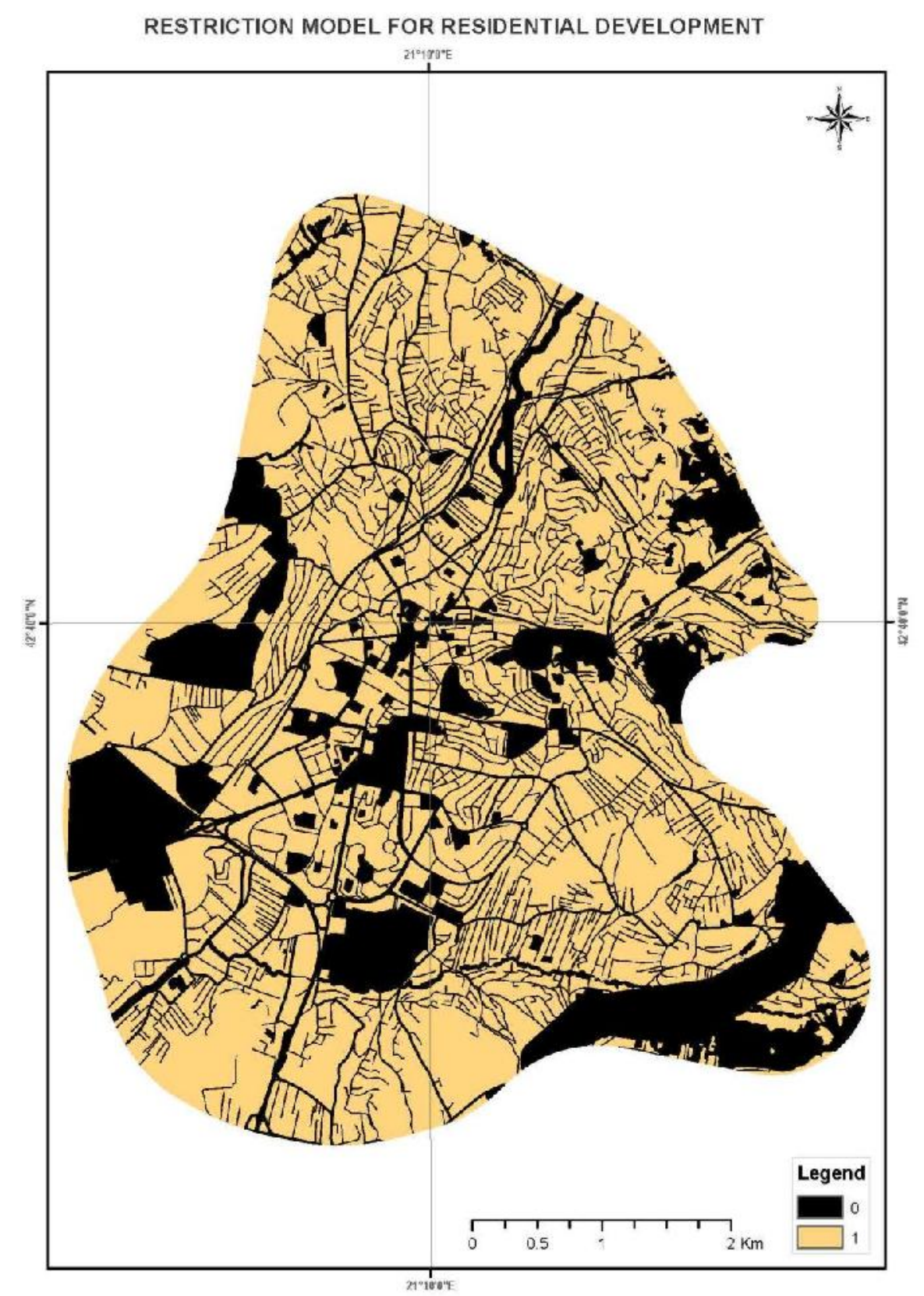

Fig. 3. The map of restriction model (By authors). 


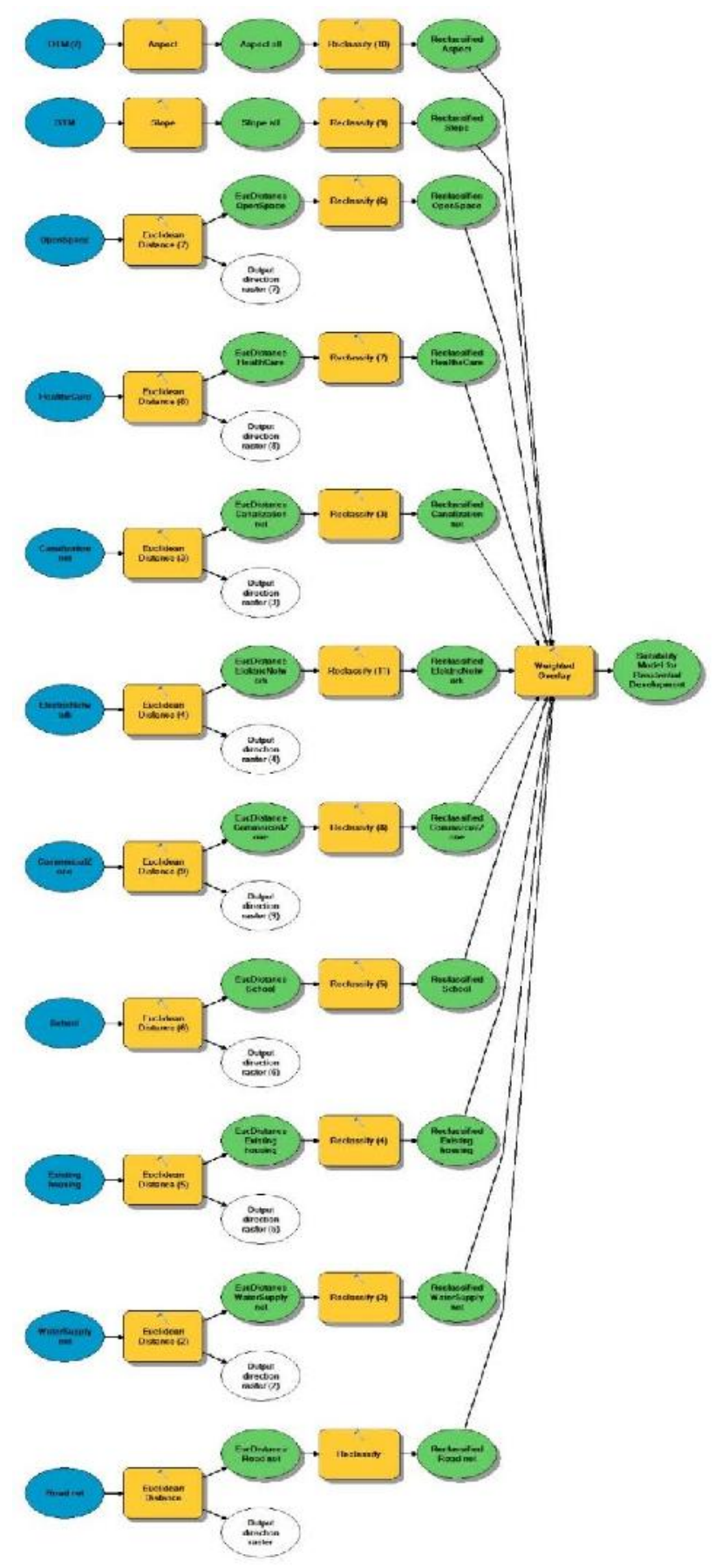

Fig. 4. Operational scheme of suitability model (By authors). 


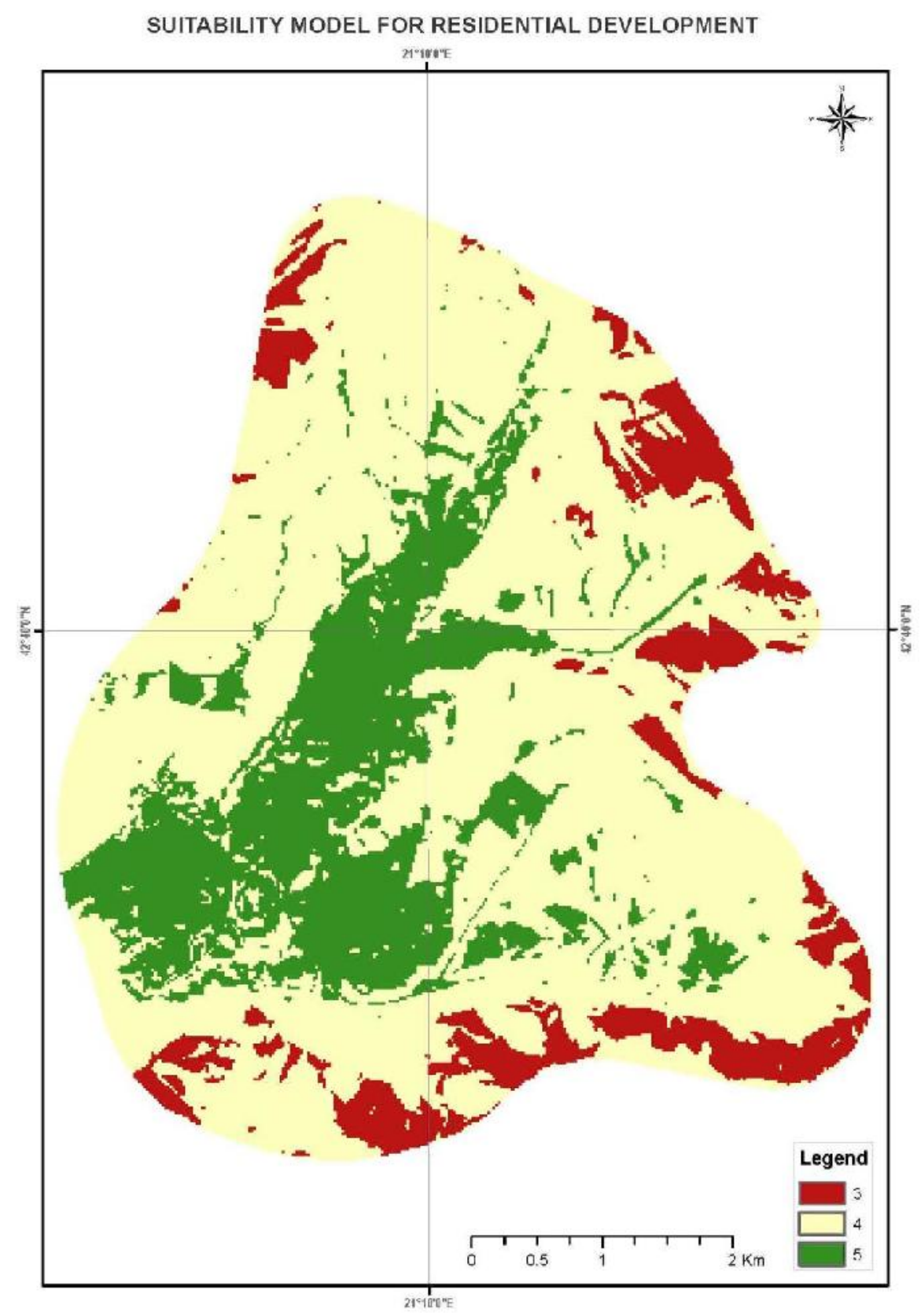

Fig. 5. The map of suitability model (By authors). 


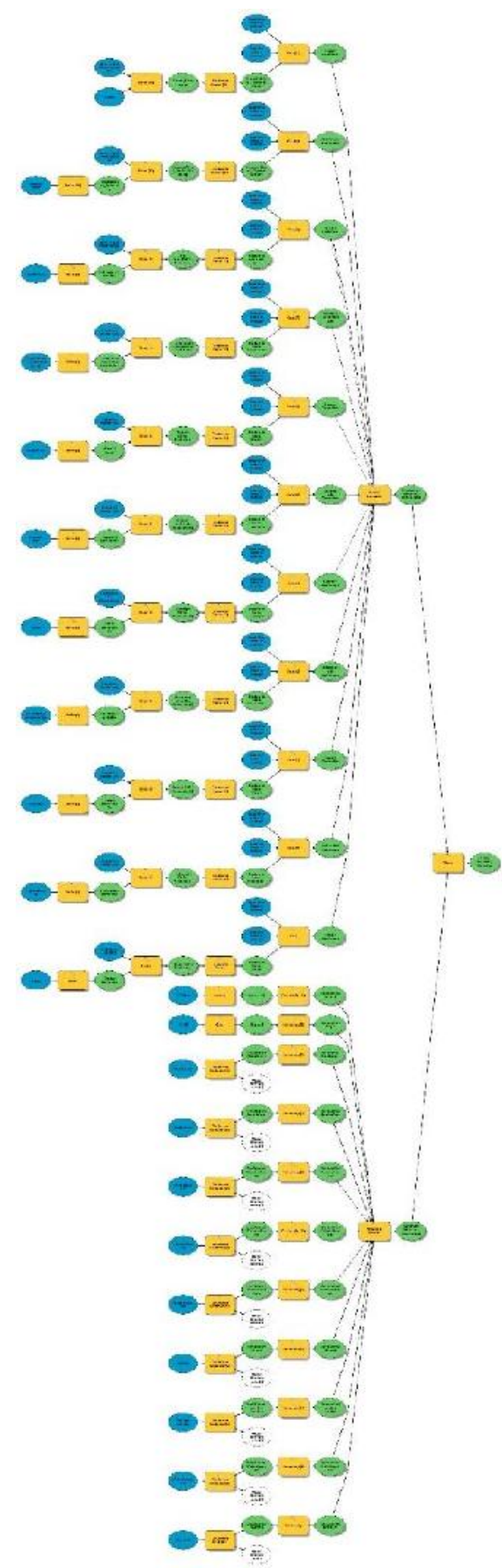

Fig. 6. Operational scheme of final suitability model (By authors). 


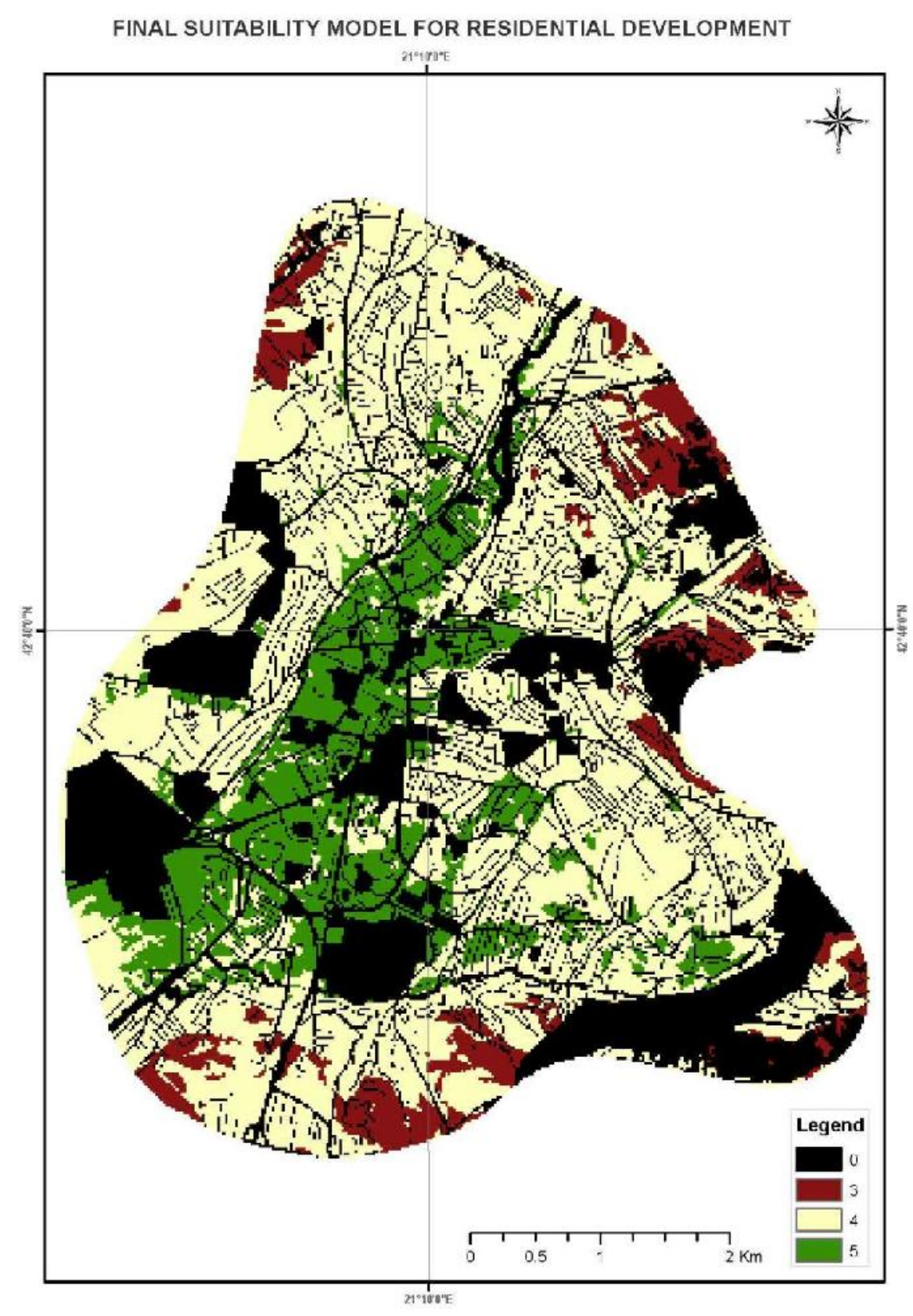

Fig. 7. The map of final suitability model (By authors). 


\section{References}

1. Wang, X., Hofe, R.: Research Methods in Urban and Regional Planning. Springer Berlin (2007) 273-326

2. Briassoulis, H.: Analysis of Land Use Change: Theoretical and Modeling Approaches. RRI. (Regional Research Institute), WVU. (West Virginia University). (2000)

3. Longley, A. P., Goodchild F. M., Maguire J. D., Rhind, W. D.: Geographic Information Systems and Science. Wiley England (2005)

4. Chan, Y.: Location Theory and Decision Analysis. Springer London and New York (2001)

5. Clifford, N., French, S., Valentine, G.: Key Methods in Geography. Sage Los Angeles London New Delhi Singapore and Washington (2010)

6. Benenson, I., Torrens, M. P.: Geosimulation (Automata-based modeling for urban phenomena). Wiley UK (2004)

7. Simsion, C. G., Witt, C. G.: Data Modeling Essentials. Library of Congress USA. Morgan Kaufmann (2005)

8. Platt, H. R.: Land Use and Society: Geography, Law, and Public Policy. Island Press (2004)

9. Nc, Division of Coastal Management, Nc, Center for Geographic Information and Analysis. Land Suitability Analysis User Guide for ArcView 3.x and ArcGIS 9.x (2005) 